\title{
Feeding and energy budgets of larval Antarctic krill Euphausia superba in summer
}

\author{
Bettina Meyer ${ }^{1, *}$, Angus Atkinson ${ }^{2}$, Bodo Blume ${ }^{1}$, Ulrich V. Bathmann ${ }^{1}$ \\ ${ }^{1}$ Alfred Wegener Institute for Polar and Marine Research, Department of Pelagic Ecosystems, Handelshafen 12, \\ 27570 Bremerhaven, Germany \\ ${ }^{2}$ British Antarctic Survey, Natural Environment Research Council, High Cross, Madingley Road, Cambridge CB3 0ET, \\ United Kingdom
}

\begin{abstract}
The physiological condition and feeding activity of the dominant larval stages of Euphausia superba (calyptopis stage III, furcilia stages I and II) were investigated from February to March 2000 at the Rothera Time Series monitoring station $\left(67^{\circ} 34^{\prime} \mathrm{S}, 68^{\circ} 07^{\prime} \mathrm{W}\right.$, Adelaide Island, Western Antarctic Peninsula). A dense phytoplankton bloom (5 to $25 \mu \mathrm{g} \mathrm{chl} \mathrm{a}{ }^{-1}$ ) occupied the mixed layer throughout the study period. The feeding of larvae was measured by incubating the animals in natural seawater. Food concentrations ranged from 102 to $518 \mu \mathrm{g} \mathrm{C}^{-1}$ across experiments, and the mean daily C rations were $28 \%$ body C for calyptosis stage III (CIII), $25 \%$ for furcilia stage I (FI) and $15 \%$ for FII. The phytoplankton, dominated by diatoms and motile prey taxa, ranged from 8 to $79 \mu \mathrm{m}$ in size. Across this size spectrum of diatoms, CIII cleared small cells most efficiently, as did FI to a lesser degree. FII, however, showed no clear tendency for a specific cell size. Across the measured size spectrum of the motile taxa, all larvae stages showed a clear preference towards the larger cells. Estimated C assimilation efficiencies were high, from 70 to $92 \%$ (mean $84 \%$ ). Respiration rates of freshly caught larvae were 0.7 to $1.1 \mathrm{\mu l} \mathrm{O}_{2} \mathrm{mg} \mathrm{DM}^{-1} \mathrm{~h}^{-1}$. The calculated respiratory $\mathrm{C}$ loss showed a significant increase with increasing food concentration in all larval stages, ranging from 0.9 to $2.4 \%$ body $\mathrm{C} \mathrm{d}^{-1}$. These respiratory losses, combined with the high assimilation efficiencies, thus give the larvae ample capacity for growth at these food concentrations. Critical concentrations of food to achieve maximum daily rations

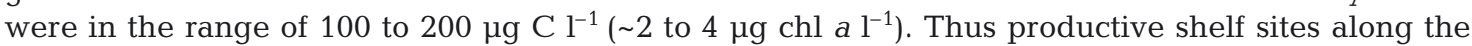
Antarctic Peninsula, such as Rothera, may act as good 'nursery' areas for krill larvae.
\end{abstract}

KEY WORDS: Antarctic krill · Euphausia superba · Larval krill · Energy budget Resale or republication not permitted without written consent of the publisher

\section{INTRODUCTION}

Planktonic larvae are a critical life-cycle phase of many marine species, and their survival and growth influence population success (e.g. Daly 1990, Ross \& Quetin 1991). Turnover rates and recruitment success of euphausiids are of particular interest because of their important role in the ecosystems they occupy, many of which are sites for commercial fisheries. Mortality rates of euphausiid larvae can be over $90 \% \mathrm{mo}^{-1}$ (Siegel 2000a,b), and these rates are highly variable. However, we have only cursory information on the ecology of euphausiid larvae, even for the best-known species, Antarctic krill.
The Antarctic krill Euphausia superba (hereafter 'krill') is the primary prey for many predators in Antarctic waters. It has key status in the Southern Ocean and occupies a central place in commercially valuable food webs. Most of the information on krill is for adults during the Antarctic summer, with little yet known of its larval ecology. Most studies on krill larvae address their regional distribution patterns (e.g. Fraser 1936, Hempel 1985, Frazer et al. 1997, Siegel 2000b) and ecophysiological field studies are scarce (Ikeda 1981, Brinton \& Townsend 1984, Daly 1990, Huntley \& Brinton 1991, Frazer et al. 2002, Meyer et al. 2002).

Euphausiids develop through a series of larval stages with different critical phases. Larval krill appear dur- 
ing summer, develop during their first dark season, and moult to juveniles before December. Ross \& Quetin (1991) defined 2 critical phases for these larvae: firstly at the appearance of the first feeding stage, calyptopis I (CI), and secondly the survival of their furcilia stages during winter. The larvae have low lipid reserves and can only survive a few weeks without food (Ross \& Quetin 1991, Meyer et al. 2002), so food shortage appears to be the critical factor for both of these larval periods. According to Huntley \& Brinton (1991), if larvae can develop to furcilia stages by April, they are likely to survive the winter and to appear the following spring as either later-stage furcilia or early juveniles.

The aim of the study was to investigate the physiological condition of krill larvae by studying the functional relationships of feeding, assimilation, and respiration on food availability. Given the influential role of krill in the Antarctic community, an understanding of the physiological condition of their larval stages before entering the winter season might give insights into their recruitment success in the region off Rothera, Adelaide Island (Western Antarctic Peninsula). The present study is integrated in the Southern Ocean Global Ocean Ecosystems Dynamics Program (SOGLOBEC). One goal of this program is to examine the factors that govern krill survivorship and, hence, availability to higher trophic levels.

\section{MATERIALS AND METHODS}

Sampling. Sampling was conducted during the austral summer (February to March 2000) at the Rothera Time Series (RATS) monitoring station of the British Antarctic Survey Research Station at Rothera Point (Fig. 1). Larvae of Euphausia superba were collected from an inflatable boat using a $200 \mu \mathrm{m}$ mesh net with a $11 \mathrm{cod}$ end. The net was towed vertically by hand, slowly from $200 \mathrm{~m}$ to the surface, and the catches were transferred to 201 buckets of surface seawater. Sorting and experimental work took place at the former Bonner Laboratory at Rothera Point, $10 \mathrm{~min}$ from the sampling station. Larvae were sorted under a binocular microscope and identified following Fraser (1936). Calyptopis III (CIII) and furcilia I and II (FI and FII) were the dominant stages during the investigation.

One fraction of freshly caught larvae was frozen immediately on a $200 \mu \mathrm{m}$ mesh and stored at $-80^{\circ} \mathrm{C}$ for later analyses of length, dry mass, elemental (C, N) and biochemical composition (total lipid, protein, and carbohydrate) at the Alfred Wegener Institute, Germany. The other fraction was used for experiments on feeding rates, assimilation efficiency and oxygen uptake rates.

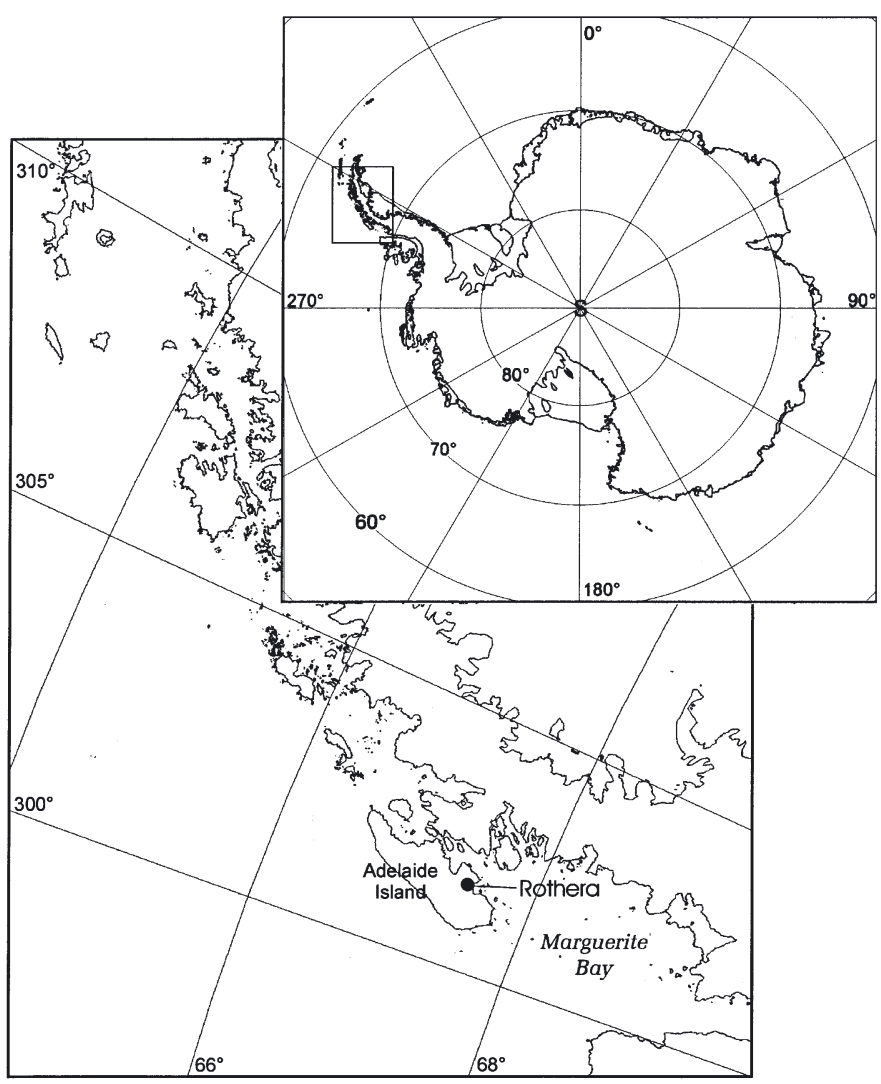

Fig. 1. Location of the British Antarctic Survey station Rothera

All experiments and handling of larvae was done in a temperature constant room at $0^{\circ} \mathrm{C}$. Within $\sim 1 \mathrm{~h}$ of capture, the larvae were sorted by stage into 3 Plexiglas aquaria filled with $20 \mathrm{l}$ of natural seawater, using a $300 \mu \mathrm{m}$ mesh spoon. Within 2 to $3 \mathrm{~h}$ of sorting, experiments were started.

Feeding experiments. Feeding experiments were conducted using natural seawater collected by bucket from the surface at the jetty at Rothera. This is close to deep water and is in the same oceanic regime as the nearby Rothera monitoring station. The water was transferred to an acid-washed 501 aspirator and transported to the experimental cold room $\left(0^{\circ} \mathrm{C}\right)$. From the mixed contents of the aspirator, a $220 \mathrm{ml}$ subsample was siphoned and fixed in $1 \%$ Lugol's solution for cell counting and 2 replicates of $220 \mathrm{ml}$ were taken for chl $a$ analysis. These were filtered onto Whatman GF/F filters, sonicated on ice for $30 \mathrm{~s}$ with $10 \mathrm{ml}$ of $90 \%$ aqueous Acetone, and centrifuged $(700 \times g)$ for $3 \mathrm{~min}$. The supernatant was used to measure chl a with a Turner 700D fluorometer (see Wright et al. 1997).

The mixed aspirator contents were siphoned through silicon tubing into $2.4 \mathrm{l}$ grazing bottles. Each experiment comprised 3 to 5 replicate bottles per larval stage (15 CIII, 10 FI or 5 FII) and 4 controls without larvae. 
Bottles were then incubated on a plankton wheel $(0.5 \mathrm{rpm})$ in the dark for $24 \mathrm{~h}$ at $0^{\circ} \mathrm{C}$.

At the end of the experiment, animals were checked for mortality and subsamples were siphoned for cell counts and chl a analyses, as described above. In addition, a $220 \mathrm{ml}$ subsample was taken from each bottle for particulate organic carbon (POC) analysis. This was filtered onto a pre-combusted GF/F filter and frozen at $-80^{\circ} \mathrm{C}$ for later analysis. POC was measured by drying filters at $60^{\circ} \mathrm{C}$ for $12 \mathrm{~h}$, pelletising them and analysing in a Carlo Erba $\mathrm{CN}$ analyser against an acetanilide standard.

Analysis of feeding experiments. Phytoplankton cell concentrations were determined by inverted microscopy at $\times 100$ and $\times 400$ magnification after settling aliquots of $20 \mathrm{ml}$ in counting chambers. Identification of phytoplankton was based on Priddle \& Fryxell (1985), Medlin \& Priddle (1990), and Thomas et al. (1996). Three replicates were counted from each experiment and the mean of these was used for further calculations. The standard deviation of replicates was $<12 \%$ of the mean. Cell counts and sizes were converted into $\mathrm{C}$ equivalents via biovolume according to Menden-Deuer \& Lessard (2000). Chl a concentration was converted to $C$ equivalents using the $C$ :chl a ratios estimated in each experiment via the measured POC concentration $\left(\mathrm{C}_{(\mathrm{POC})}\right.$ : $\left.\mathrm{Chl} a\right)$. This ratio ranged between 18 and 58 during the study period.

Feeding rate calculations. Clearance rates on the total $\mathrm{C}$ biomass and on individual cell taxa were calculated from Frost's (1972) equation modified to:

$$
F=\ln \left(C_{\mathrm{c}} / C_{\mathrm{k}}\right) \times V / m_{\mathrm{k}} t
$$

where $F$ is the clearance rate $\left(\mathrm{ml} \mathrm{mg}^{-1}\right.$ body $\left.\mathrm{C} \mathrm{h}^{-1}\right), C_{\mathrm{c}}$ is the final concentration in the control, $C_{\mathrm{k}}$ is the final concentration in the incubation bottles grazed by the larvae, $V$ is the experimental volume $(\mathrm{ml}), m_{\mathrm{k}}$ is the body mass (mg C) of larvae, and $t$ is the experimental duration (h).

Ingestion rates on the total algal biomass were calculated as the product of the clearance rate on the total algal biomass $\left(\mathrm{ml} \mathrm{mg}{ }^{-1}\right.$ larvae body $\mathrm{C} \mathrm{h}^{-1}$ ) and its $\mathrm{C}$ concentration in the final control $\left(\mathrm{mg} \mathrm{C} \mathrm{ml}^{-1}\right)$. Ingestion rates were then expressed as a daily $\mathrm{C}$ ration under the assumption that larvae feeding rates recorded during each incubation reflect the daily average rate. The depletion of $\mathrm{C}$ biomass was between 10 and $15 \%$ in all experiments.

Estimation of assimilation efficiency. Assimilation efficiency was estimated by a budget method based on ratios, which however differs from the more established ratio methods based on an inert tracer (Båmstedt et al. 2000). It uses parallel measurements of the decrease in chl $a$ and POC in the control and experimental bottles. It is based on the principles that the decrease in chl $a$ is due to grazing, and because of gut enzyme activity, ingested chl $a$ is almost entirely transformed to its derivatives, with only trace amounts of chl a in faecal pellets (G. C. Cripps, British Antarctic Survey, unpubl. data, see also Båmstedt et al. 2000). The parallel decrease in total POC in the grazer bottle also represents grazing, but its smaller decrease, relative to chl $a$, reflects the fact that a measurable proportion of that ingested is not assimilated into the animal, but remains in the faecal pellets.

Assimilation efficiency, $A$, was thus calculated as the ratio of the proportional decrease in chl a to that of POC within the grazed and control bottles at the end of the experiment. This can be rearranged to:

$$
A=\left(\operatorname{chl} a_{\exp } \times \mathrm{POC}_{\text {con }}\right) /\left(\operatorname{chl} a_{\text {con }} \times \mathrm{POC}_{\text {exp }}\right)
$$

where chl $a_{\exp }=\operatorname{chl}$ a concentration in experimental container (i.e. the water and faecal pellets) at the end of the experiment, $\operatorname{chl} a_{\text {con }}=\operatorname{chl} a$ concentration in experimental container (i.e. the water) at the end of experiment, $\mathrm{POC}_{\exp }=\mathrm{POC}$ concentration in experimental container (i.e. the water and faecal pellets) at end of experiment, and $\mathrm{POC}_{\mathrm{con}}=\mathrm{POC}$ concentration in control (i.e. the water) at end of experiment.

This black-box approach thus compares the incubation water of the control with the incubation water plus faecal pellets of the grazed container. Significant quantities of unassimilated food within the grazer guts at the time of final sampling would mean an underestimation of assimilation efficiency. However, given that gut passage times of furcilia are short $(1$ to $2 \mathrm{~h}$; E. A. Pakhomov unpubl. data) relative to the $24 \mathrm{~h}$ incubations, such underestimation would be slight. The other assumptions are that krill grazing was the dominant process reducing chl a and POC concentrations during the experimental period and that there was not significant re-ingestion or breakdown of faecal pellets. Therefore, we stress that the values obtained from these methods are estimates, given that we have not done parallel measurements with more established techniques.

Respiration rate measurements. Oxygen uptake rates were measured both on freshly caught larvae and on larvae immediately after each feeding experiment (Table 1). The larval krill (15 of CIII, 10 of FI or 5 of FII) were incubated in sealed $1.5 \mathrm{l}$ bottles filled with filtered seawater $(0.45 \mu \mathrm{m}$ pore size) for $24 \mathrm{~h}$ at $0^{\circ} \mathrm{C}$. Each respiration measurement comprised 3 to 4 replicates with larvae of each stage and 3 controls without larvae. Oxygen concentration was measured with the colorimetric method (Peck \& Whitehouse 1992). Each bottle was analysed in triplicate by using 3 water samples of $500 \mu \mathrm{l}$ each. The analytical variance of triplicates was $<1 \%$. The decrease of oxygen 
concentration in the experiments was between 3 and $7 \%$, which is believed not to affect larval respiration (Johnson et al. 1984).

Morphometrics, elemental and biochemical composition. The body lengths (BLs) of larvae were measured from the front of the eye to the tip of the telson under the stereomicroscope. Individuals were then freeze-dried and their dry masses (DMs) and C and $\mathrm{N}$ contents were determined as described by Meyer et al. (2002). Replicate batches of 5 of CIII, 3 of FI and 2 of FII were used for each analysis, following the procedure in Donnelly et al. (1990). We analysed 20 replicates in CIII, 17 in FI and 6 in FII.

Total protein and carbohydrates were measured by homogenising 1 sample in $4 \mathrm{ml}$ of $5 \%$ Trichloroacetic acid (TCA) on crushed ice using a Branson Sonifer B15 cell disrupter. After centrifugation at $6000 \mathrm{rpm}$ $(5000 \times g)$ for $10 \mathrm{~min}$, the supernatant was used for measuring carbohydrates according to Holland \& Gabbott (1971), using glucose as a standard. The remaining pellet was used for protein analysis after Lowry et al. (1951) with bovin serum albumin as a standard. Each sample comprised replicate batches of 3 individuals of CIII, 2 of FI and 2 of FII.

Total lipid was measured photometrically with a Merckotest reagent (Merck), utilising the sulphophosphovanillin reaction (Zöllner \& Kirsch 1962). Each sample comprised replicate batches of 5 individuals of CIII, 3 of FI and 3 of FII.

Total protein and lipid were analysed in 10 replicates in CIII and FI and in 5 replicates in FII.

Statistical analyses. Selective feeding towards a specific cell size was characterised using a regression between clearance rate of larvae against cell size of food items. The Student's $t$-test was used to test the significance of differences between larvae stages on clearance rates, daily ration, assimilation efficiencies and respiration rates.

\section{RESULTS}

\section{Environment and larval distribution}

During the investigation, seawater temperature within the upper $200 \mathrm{~m}$ ranged from -0.6 to $0.5^{\circ} \mathrm{C}$ and salinity was always $>33 \%$. A dense phytoplankton

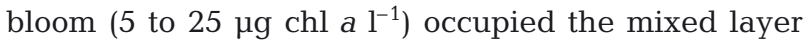
throughout the study period (A. Clarke, British Antarctic Survey, unpubl. data).

Larvae were numerous whenever we sampled. However, nets fished consecutively within the top 90 and $200 \mathrm{~m}$ revealed that most resided below $90 \mathrm{~m}$ on all the afternoons of sampling. During the study period the ambient chl a concentrations of the feeding experiments ranged from 5.8 to $10.7 \mu \mathrm{g} \mathrm{chl} \mathrm{a}^{-1}$ and the POC

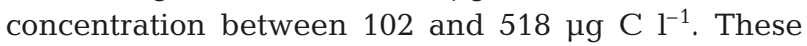
values were similar to the carbon biomass estimated from cell counts and sizes via biovolume conversions $\left(\mathrm{C}_{(\mathrm{CC})}: 147\right.$ to $510 \mu \mathrm{g} \mathrm{l}^{-1}$, Table 1$)$.

\section{Morphometrics and body composition}

BL, DM, elemental and biochemical composition of CIII, FI and FII are shown in Table 2. The BL and DM increased by ca. $30 \%$ from CIII to FI and by ca. $18 \%$ from FI to FII, whereas the increase in DM from one stage to another was $50 \%$. The contribution of C and $\mathrm{N}$ to the DM was similar in all stages (Table 2).

The regression of DM $(\mu \mathrm{g})$ on BL $(\mathrm{mm})$ was:

$$
\begin{array}{ll}
\text { CIII: } & \log _{10}(\mathrm{DM})=8.8 \log _{10}(\mathrm{BL})-3.6 \\
& \mathrm{r}=0.916, \mathrm{p}<0.001, \mathrm{n}=20 \\
\text { FI: } & \log _{10}(\mathrm{DM})=5.9 \log _{10}(\mathrm{BL})-2.1 \\
& \mathrm{r}=0.843, \mathrm{p}<0.001, \mathrm{n}=17 \\
\text { FII: } & \log _{10}(\mathrm{DM})=11 \log _{10}(\mathrm{BL})-6.8 \\
& \mathrm{r}=0.938, \mathrm{p}<0.01, \mathrm{n}=6
\end{array}
$$

Table 1. Euphausia superba. Overview of the experiments conducted with the different larvae stages, calyptopis III (CIII), furcilia

\begin{tabular}{|c|c|c|c|c|c|c|}
\hline $\begin{array}{l}\text { Start of experimen } \\
\text { (dd/mm/yy) }\end{array}$ & at Feeding rates & 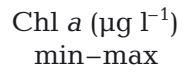 & $\begin{array}{c}\mathrm{C}_{(\mathrm{CC})}\left(\mu \mathrm{g} \mathrm{l}^{-1}\right) \\
\min -\max \end{array}$ & $\begin{array}{c}\mathrm{C}_{(\mathrm{POC})}\left(\mu \mathrm{g} \mathrm{l}^{-1}\right) \\
\min -\max \end{array}$ & $\begin{array}{l}\text { Oxygen uptake } \\
\text { rates (I) }\end{array}$ & $\begin{array}{l}\text { Oxygen uptake } \\
\text { rates (II) }\end{array}$ \\
\hline $28 / 02 / 00$ & CIII (3), FI (3) & $5.8-6.8$ & $147-251$ & $302-393$ & & \\
\hline $29 / 02 / 00$ & CIII (3), FI (3) & $7.9-8.9$ & $338-408$ & $367-390$ & CIII (3), FI (3) & \\
\hline $30 / 02 / 00$ & & & & & CIII (3), FI (3) & \\
\hline $01 / 03 / 00$ & CIII (3), FI (5), FII (3) & $8.1-9.3$ & $405-515$ & $393-496$ & & \\
\hline $02 / 03 / 00$ & CIII (3), FI (4) & $7.8-9.6$ & $306-493$ & $423-507$ & CIII (3), FI (5), FII (3) & CIII (3), FII (3) \\
\hline 06/03/00 & CIII (3), FI (5), FII (3) & $9.9-10.7$ & $498-510$ & $501-519$ & & \\
\hline $07 / 03 / 00$ & CIII (5) & $9.4-10.3$ & $322-425$ & $398-465$ & CIII (3), FI (5), FII (3) & FII (3) \\
\hline
\end{tabular}
I and II (FI, FII), and the concentration of available food in the incubation bottles, expressed in terms of chl a and carbon. The number in brackets gives the number of replicate bottles of a specific larval stage in a experiment at a specific date. $\mathrm{C}_{(\mathrm{CC})}$ is the carbon biomass estimated by conversion of cell counts and sizes into carbon equivalents and $\mathrm{C}_{(\mathrm{POC})}$ is particulate organic carbon (POC) estimated by the $\mathrm{CN}$ analyser. Oxygen uptake rates (I) were measured with larvae from the former feeding experiment and oxygen uptake rates (II) with freshly caught larvae 
Table 2. Euphausia superba. Mean \pm SD of body length (BL), dry mass $(D M)$, elemental composition $(C, N)$ and biochemical composition of freshly caught calyptopis III (CIII), furcilia I (FI) and II (FII). Carbohydrates $=\mathrm{CH}, \mathrm{n}=$ number of replicates

\begin{tabular}{|lccc|}
\hline & CIII & FI & FII \\
\hline & $(\mathrm{n}=20)$ & $(\mathrm{n}=17)$ & $(\mathrm{n}=6)$ \\
BL $(\mathrm{mm})$ & $4.7 \pm 0.1$ & $6.1 \pm 0.2$ & $7.2 \pm 0.1$ \\
DM $(\mu \mathrm{g})$ & $219.3 \pm 39.0$ & $339.8 \pm 60.8$ & $508.8 \pm 84.1$ \\
C $(\% \mathrm{DM})$ & $35.6 \pm 2.6$ & $37.5 \pm 2.3$ & $38.6 \pm 2.9$ \\
N (\% DM) & $8.7 \pm 0.7$ & $8.9 \pm 0.5$ & $8.6 \pm 1.5$ \\
C:N ratio & $4.1 \pm 0.2$ & $4.2 \pm 0.1$ & $4.6 \pm 0.7$ \\
& $(\mathrm{n}=10)$ & $(\mathrm{n}=10)$ & $(\mathrm{n}=5)$ \\
Lipid (\% DM) & $19.7 \pm 3.6$ & $16.1 \pm 1.2$ & $13.8 \pm 8.3$ \\
Protein (\% DM) & $34.4 \pm 7.1$ & $34.2 \pm 6.3$ & $24.8 \pm 8.9$ \\
CH (\% DM) & $6.9 \pm 1.1$ & $3.8 \pm 0.8$ & $3.0 \pm 1.4$ \\
& & & \\
\hline
\end{tabular}

The mean lipid content as a \% of DM was $20 \%$ in CIII and decreased in FI and FII from 16 to $14 \%$. However there was high variability among FII stages, ranging between 6 and $22 \%$ of DM (Table 2). Protein was $34 \%$ of DM in CIII and FI and $25 \%$ in FII. Carbohydrate $(\mathrm{CH})$ decreased from $7 \%$ of DM in CIII, to less than $4 \%$ in the furcilia stages.

The relative content of $\mathrm{CH}$ in CIII was exceptionally high, because among marine zooplankton the $\mathrm{CH}$ content generally ranges from 2 to $5 \%$ of DM (Mauchline et al. 1998). We suggest that the high $\mathrm{CH}$ content in CIII is an indicator of forthcoming moulting. Shortly before ecdysis, arthropods enzymatically degrade a part of their carapace chitin, which is a nitrogeneous polysaccharide. The resulting monomers (N-Acetyl- $\beta$-Dglucosamin) are absorbed and, after moulting, are reused in the synthesis of the new cuticle (Paulus 1996).

\section{Grazing activity and selectivity}

The daily $\mathrm{C}$ rations, based on the measured POC concentration in the grazing experiments, ranged between 16 and $49 \%$ body C in CIII, from 14 to $43 \%$ body $\mathrm{C}$ in FI and 11 to $18 \%$ body C in FII (Fig. 2). None of the 3 larval stages showed a significant increase in the daily $\mathrm{C}$ ration with increasing food concentration, but their clearance rates $\left(\mathrm{ml} \mathrm{mg}\right.$ body $\mathrm{C}^{-1} \mathrm{~h}^{-1}$ ) decreased with increasing food availability $\left(\mu \mathrm{g} \mathrm{C} \mathrm{l}^{-1}\right.$, Fig. 3) and are expressed below, based on all data points of each larval stage:

CIII: clearance rate $=-19.72 \ln$ (available food $)+142.37$, $\mathrm{r}=0.502, \mathrm{p}<0.01, \mathrm{n}=18$

FI: clearance rate $=-17.34 \ln ($ available food $)+125.88$, $\mathrm{r}=0.790, \mathrm{p}<0.001, \mathrm{n}=16$

FII: clearance rate $=-8.71 \ln ($ available food $)+66.91$, $\mathrm{r}=0.813, \mathrm{p}<0.05, \mathrm{n}=6$
The daily $\mathrm{C}$ rations and the clearance rates of FII were significantly lower than in the younger stages with respect to the available food concentration (Figs. $2 \& 3, \mathrm{p}<0.05)$.

In the incubation water, large Thalassiosira sp., Chaetoceros sp. and Dactyliosolen sp. dominated the phytoplankton composition during the study period and were also accompanied by a varied motile taxa assemblage (Table 3). In this group the dinoflagellates were dominated by hetrotrophic forms such as Protoperidinium and Gyrodinium. The clearance rates on the different food items are shown in Fig. 4. We describe the preference of larvae on a specific food size via regression between clearance rate of larvae ( $\mathrm{ml} \mathrm{mg}$ body $\mathrm{C}^{-1} \mathrm{~h}^{-1}$ ) towards cell size $(\mu \mathrm{m}$ length) of (a) diatoms and (b) motile taxa, based on all data points

(a) CIII: clearance rate $=-0.43$ (cell size) +57.43 , $\mathrm{r}=0.535, \mathrm{p}<0.001, \mathrm{n}=162$

FI: clearance rate $=-0.28$ (cell size) +44.63 , $\mathrm{r}=0.503, \mathrm{p}<0.001, \mathrm{n}=144$

FII: clearance rate $=0.06$ (cell size) +17.86 , $\mathrm{r}=0.227, \mathrm{p}>0.05, \mathrm{n}=54$

(b) CIII: clearance rate $=0.187$ (cell size) +13.08 , $\mathrm{r}=0.528, \mathrm{p}<0.001, \mathrm{n}=72$

FI: clearance rate $=0.246$ (cell size) +10.23 , $\mathrm{r}=0.986, \mathrm{p}<0.001, \mathrm{n}=64$

FII: clearance rate $=0.309($ cell size $)+4.216$, $\mathrm{r}=0.645, \mathrm{p}>0.001, \mathrm{n}=24$

Within the measured size spectrum of diatoms, CIII thus cleared the smaller cells most efficiently. The same was true for FI, albeit to a lesser degree. However, FII showed no such significant trend with diatom size. Across the measured size spectrum of motile taxa, all larval stages showed significantly higher clearance rates on the larger cells.

\section{Assimilation efficiency and metabolic rates}

The estimated $\mathrm{C}$ assimilation efficiency ranged from 70 to $92 \%$, with no significant trend between stages or with food concentration (Fig. 5, p > 0.05). The mean respiration rate increased from CIII to FII from 0.7 to $1.1 \mu \mathrm{O}_{2} \mathrm{mg} \mathrm{DM}^{-1} \mathrm{~h}^{-1}$, but rates were not significantly different between stages ( $p>0.01$ ). For calculating an energy budget we expressed the oxygen uptake rates as daily $\mathrm{C}$ losses of each larval stage. O:N ratios calculated in previous studies have shown that, when enough food is available, lipids are the primary metabolic substrate (Frazer et al. 2002, Meyer et al. 2002). In the present study food was not limited, so, according to 

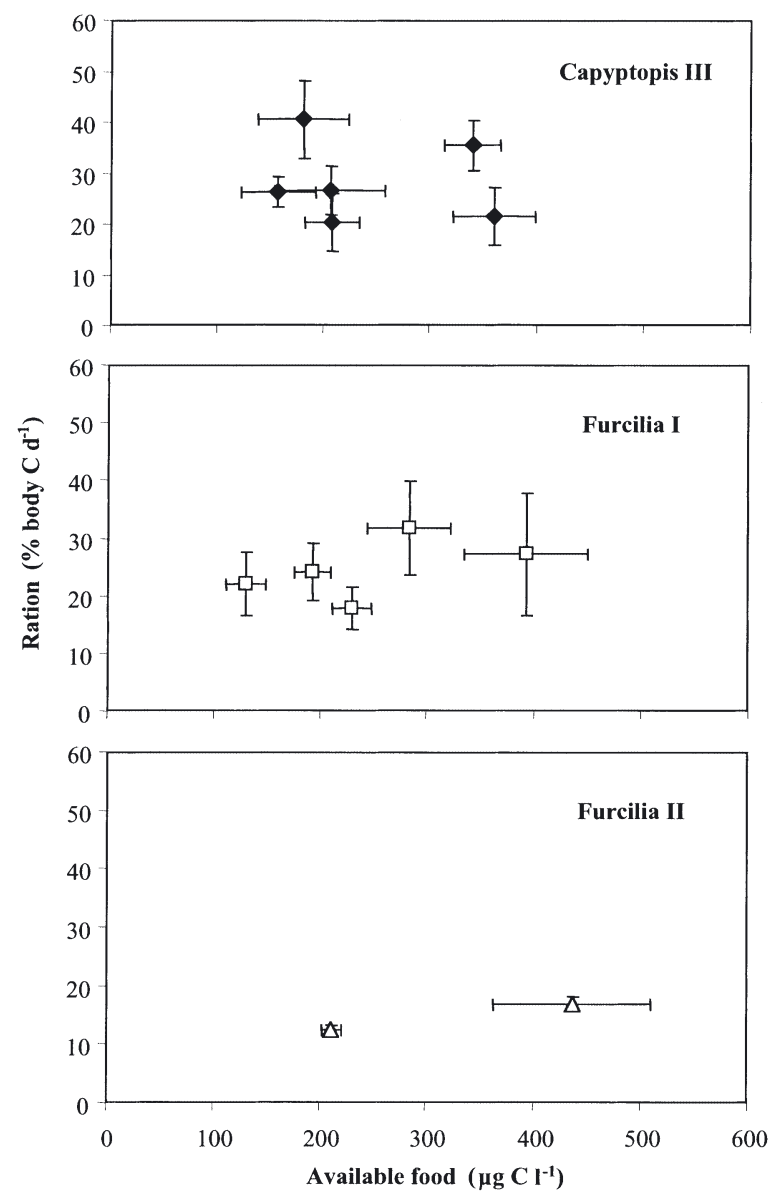

Fig. 2. Euphausia superba. Calyptopis III (CIII), furcilia I and II (FI, FII). Daily carbon rations versus food concentration. Bars indicate \pm SD of the mean of 3 to 5 replicate bottles from each experiment

Ikeda et al. (2000), a respiratory quotient of 0.72 was used. For all larval stages, the daily $\mathrm{C}$ loss ranged from 0.9 to $2.4 \%$ body $\mathrm{C}$ and increased significantly with food concentration (Fig. 6). It is expressed by the following functions, based on all data points of each larval stage, where $y$ is the daily $\mathrm{C}$ loss in \% body $\mathrm{C} \mathrm{d}^{-1}$ and $x$ is the available food in $\mu \mathrm{C} \mathrm{Cl}^{-1}$ :

CIII: daily $\mathrm{C}$ loss $=0.007$ (available food) +0.424 , $\mathrm{r}=0.966, \mathrm{p}<0.001, \mathrm{n}=15$

FI: daily C loss $=0.003$ (available food) +0.589 , $\mathrm{r}=0.992, \mathrm{p}<0.001, \mathrm{n}=16$

FII: daily C loss $=0.003$ (available food) +1.198 , $\mathrm{r}=0.978, \mathrm{p}<0.001, \mathrm{n}=12$

\section{DISCUSSION}

In some regions and seasons, krill abundance is dominated by their numerous larvae, and they can

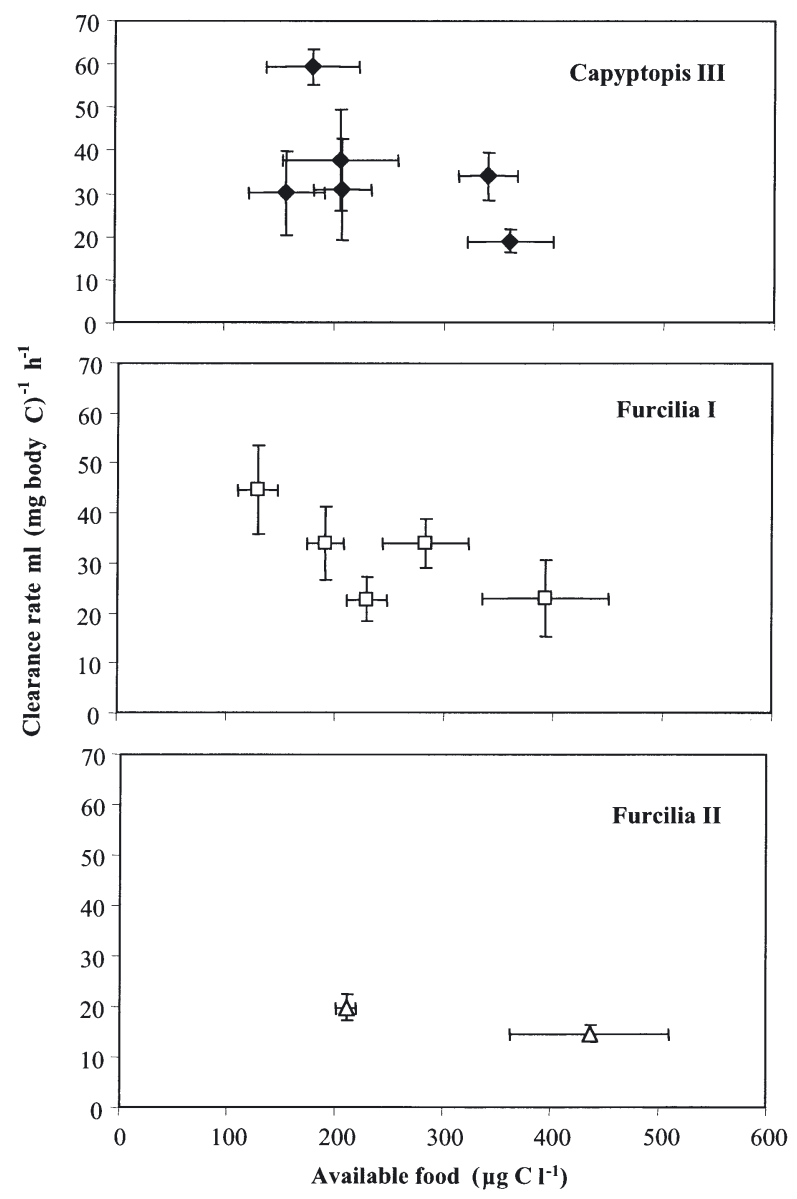

Fig. 3. Euphausia superba. Calyptopis III (CIII), furcilia I and II (FI, FII). Clearance rates versus food concentration. Bars indicate $\pm \mathrm{SD}$ of the mean of 3 to 5 replicate bottles of each experiment

Table 3. Euphausia superba. Contribution of the various size groups of phytoplankton and motile taxa in the grazing experiments of all larval stages during study period

\begin{tabular}{|lcc|}
\hline $\begin{array}{l}\text { Phytoplankton and } \\
\text { motile taxa }\end{array}$ & $\begin{array}{c}\text { Mean cell } \\
\text { length }(\mu \mathrm{m})\end{array}$ & $\begin{array}{c}\text { Contribution to } \\
\text { total biomass (\%) }\end{array}$ \\
\hline $\begin{array}{l}\text { Diatoms } \\
\text { Dactyliosolen spp. }\end{array}$ & 55 & $8-19$ \\
Thalassiosira sp. small & 11 & $3-6$ \\
Thalassiosira sp. large & 30 & $12-53$ \\
Chaetoceros sp. small & 8 & $2-16$ \\
Chaetoceros sp. large & 19 & $5-20$ \\
Plagiotropis spp. & 79 & $0.5-12$ \\
Odontella sp. & 64 & $6-8$ \\
Fragilariopsis sp. & 27 & $1-10$ \\
Nitzschia sp. & 68 & $0.6-6$ \\
Motile taxa & & \\
Ciliates & 33 & $1-7$ \\
Flagellates & 25 & $3-7$ \\
Tintinnids & 58 & $2-9$ \\
Dinoflagellates & 28 & $2-4$ \\
\hline
\end{tabular}




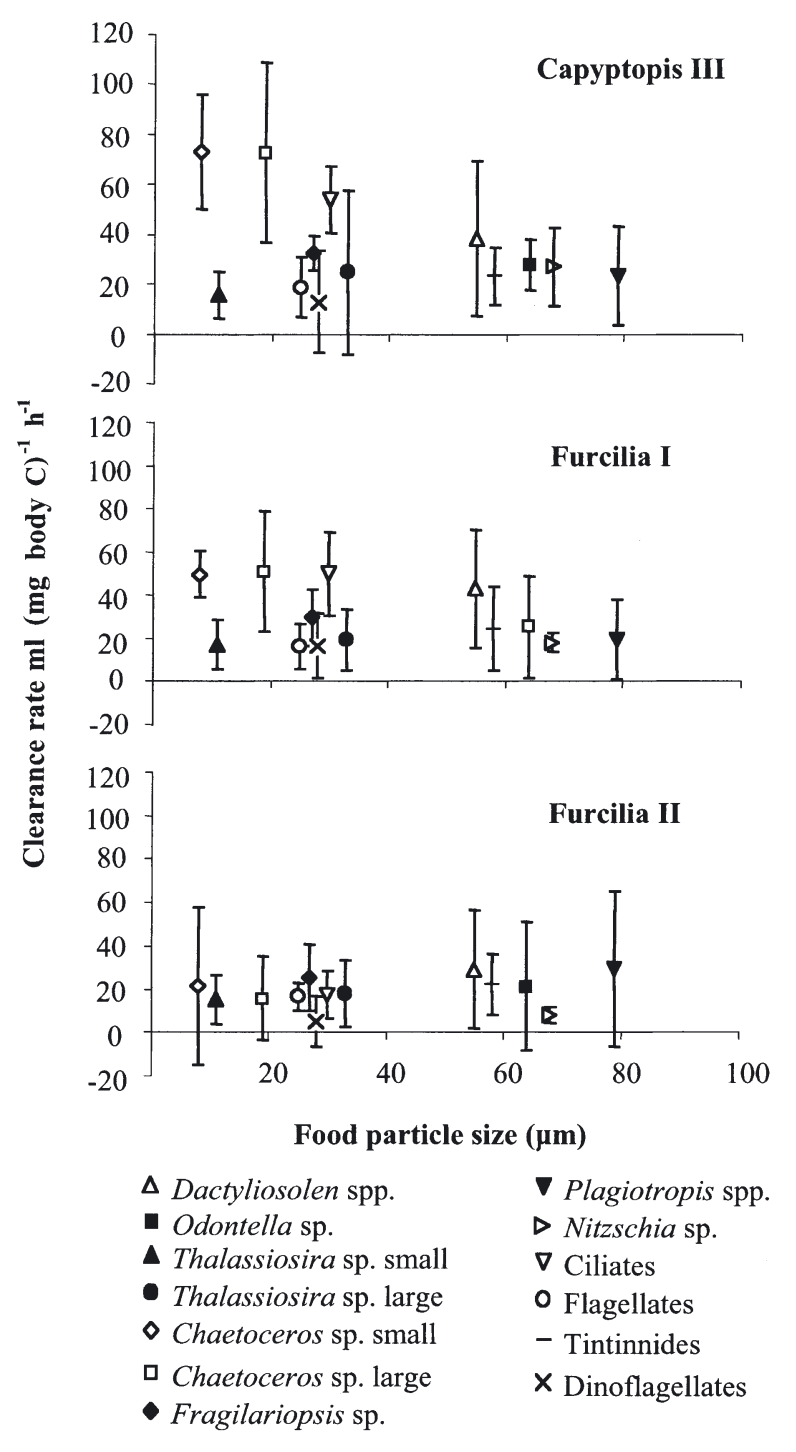

Fig. 4. Euphausia superba. Calyptopis III (CIII), furcilia I and II (FI, FII). Mass specific clearance rates on various taxa in relation to their cell size. Bars indicate $\pm \mathrm{SD}$ of the mean of 18 bottles of all experiments with CIII, 16 bottles of all experiments with FI and 6 bottles of all experiments with FII

comprise a substantial fraction of the mesozooplankton assemblage (Atkinson et al. 2002b, Ward et al. in press). However, compared to biomass-dominant copepods, we are still ignorant about the basics of their biology. A better understanding of their feeding and energy budgets firstly provides insights into recruitment success of krill. Second, it places the larvae of krill within the food web. In summer and autumn when these are most abundant, the larvae may provide an important source of energy into the food web as well as being locally important grazers.

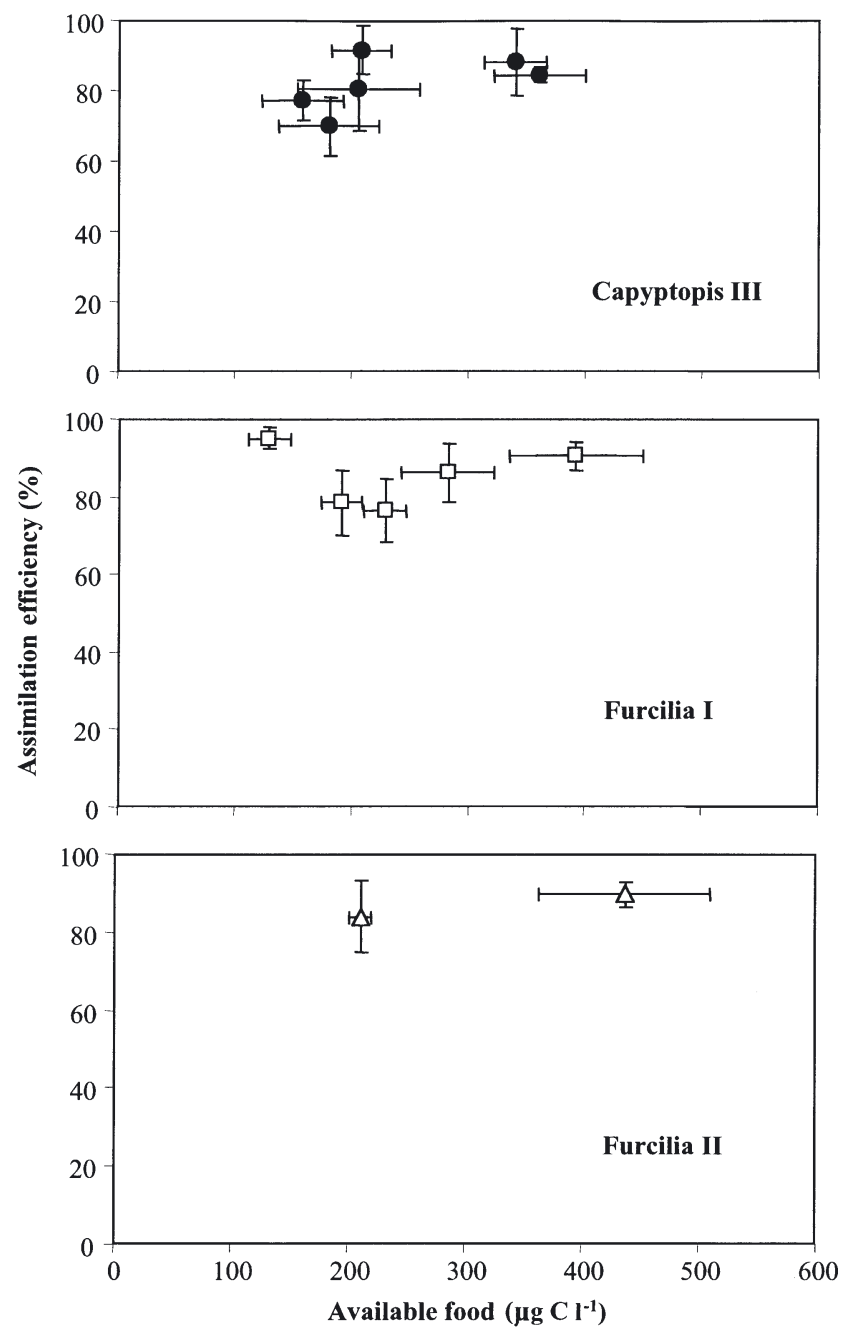

Fig. 5. Euphausia superba. Calyptopis III (CIII), furcilia I and II (FI, FII). Assimilation efficiency versus food concentration. Bars indicate $\pm \mathrm{SD}$ of the mean of 3 to 5 replicate bottles of each experiment

\section{Condition of larval krill in the field}

These data allow us to construct an energy budget for 3 stages of larval krill in summer and to assess conditions that would be food limiting. The high phytoplankton concentrations during the study (5 to $25 \mu \mathrm{g} \mathrm{chl} \mathrm{a} \mathrm{^{-1 }}$ ) are suggestive of unlimited food, resulting in the upper range of maximum BL recorded for summer krill larvae (Brinton \& Townsend 1984, Huntley \& Brinton 1991). The good energetic condition of the larvae is underlined by their high lipid contents. Hagen (1988) measured a total lipid content in calyptopes during the summer of $12 \%$, and in furcilia of $18 \%$ of DM in April/May, representing values attained after good feeding condi- 


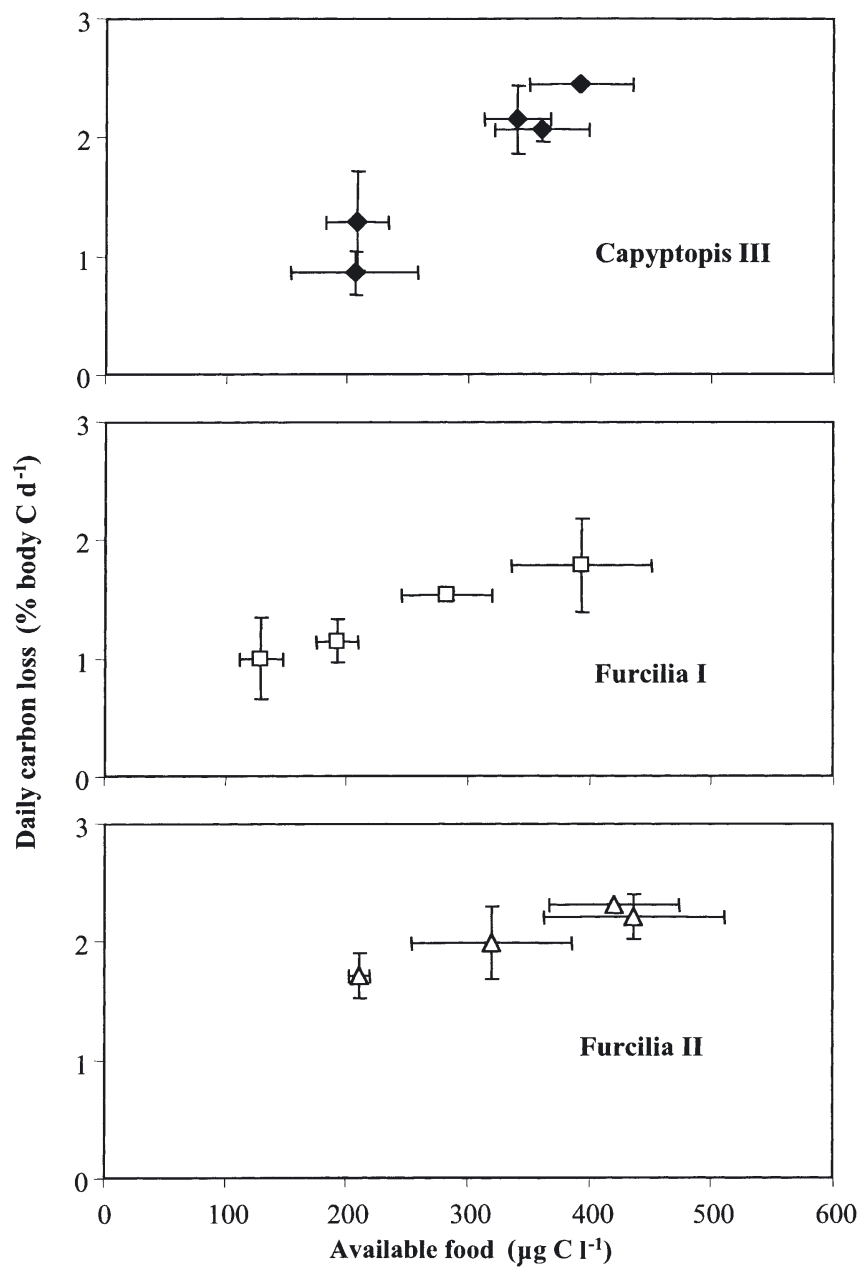

Fig. 6. Euphausia superba. Calyptopis III (CIII), furcilia I and II (FI, FII). Daily carbon losses versus food concentration. Bars indicate \pm SD of the mean of 3 to 5 replicate bottles of each experiment. The regression calculated with all data points of each larval stage is shown in the 'Results' section

tions at the onset of winter. In common with our study, Ross \& Baker (1999) reported high surface chl a values in summer within Marguerite Bay, rang-

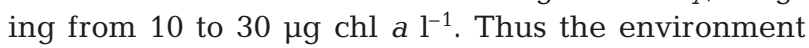
of this region may promote growth and survival of larval krill.

\section{Feeding}

We estimated the feeding activity of larvae by incubating the animals in natural seawater with ambient microplankton concentration and composition. The daily $\mathrm{C}$ ration (DR) increased with food concentration and reached mean values of $28 \%$ body C in CIII, $25 \%$ body $\mathrm{C}$ in FI and $15 \%$ body C in FII. Huntley \& Brinton (1991) reported for larval krill from the Gerlache Strait, with a mean food concentration of $3 \mu \mathrm{g} \mathrm{chl} \mathrm{a} \mathrm{l}^{-1}$, a DR of $17.8 \%$ body C for CIII to FI and $8.5 \%$ body C for FI to FII. However, Meyer et al. (2002) demonstrated, for FIII larvae from the Lazarev Sea in autumn, an increase in DR with increasing food concentration. Fig. 7 shows that maximum DR and minimum CR is reached at food concentrations in the range 100 to $200 \mu \mathrm{g} \mathrm{C} \mathrm{l}^{-1}$. This

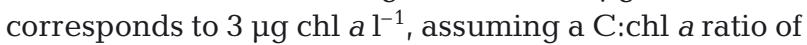

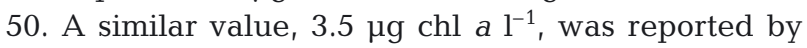
Ross et al. (2000) as a critical concentration for maximum growth of larval/postlarval krill near the end of their first year of life.

Postlarval krill can capture food from nanoplankton up to large calanoid copepods (Atkinson \& Snÿder 1997), but hardly anything is known of the feeding modes of krill larvae (Marschall 1985, Daly 1990). Meyer et al. (2002) found that FIII had no significant preference for a specific food size (range 12 to $220 \mu \mathrm{m})$. However, scanning electron microscopy observations of Marschall (1985) demonstrate that, until Stage FI, the larvae have no filter basket. This develops in FII and its prominence then increases with ontogeny. The available food that we enumerated with cell counts was in a size range of 8 to $79 \mu \mathrm{m}$ in length (Table 3). In the grazing experiments, CIII and FI cleared the smaller diatom taxa with highest rates, whereas FII larvae showed no clear preference to a specific cell size of diatoms. On the other hand, for the motile taxa all 3 stages cleared the larger cells most rapidly. These motile taxa were not cleared at higher rates than the diatom taxa, in contrast to results from similar experiments with the omnivorous copepods Metridia gerlachei and Calanus propinquus.

In bloom environments characterised by generally high quality mixtures of food, several studies have shown that suspension-feeding copepods clear all items of generally suitable and similar size with similar efficiency (Huntley 1981). More omnivorous species, however, have higher clearance rates on motile taxa (Atkinson 1995). The larvae in this study had the characteristics of the suspension-feeding copepods, such as the Antarctic species Calanoides acutus. Isotopic analyses of larval krill (including animals caught during our Rothera fieldwork) concur with this interpretation, suggesting that they occupied a lower trophic level than the omnivorous copepods Metridia gerlachei and Calanus propinquus (Schmidt et al. 2003). However, despite the motile, predominantly protozoan taxa not being cleared at noticeably faster rates than the dominant diatoms, they still comprised a substantial portion of the available food. Thus ingestion of heterotrophs undoubtedly contributed to the total $\mathrm{C}$ ration of the larvae, and probably also to their nutritional balance. 

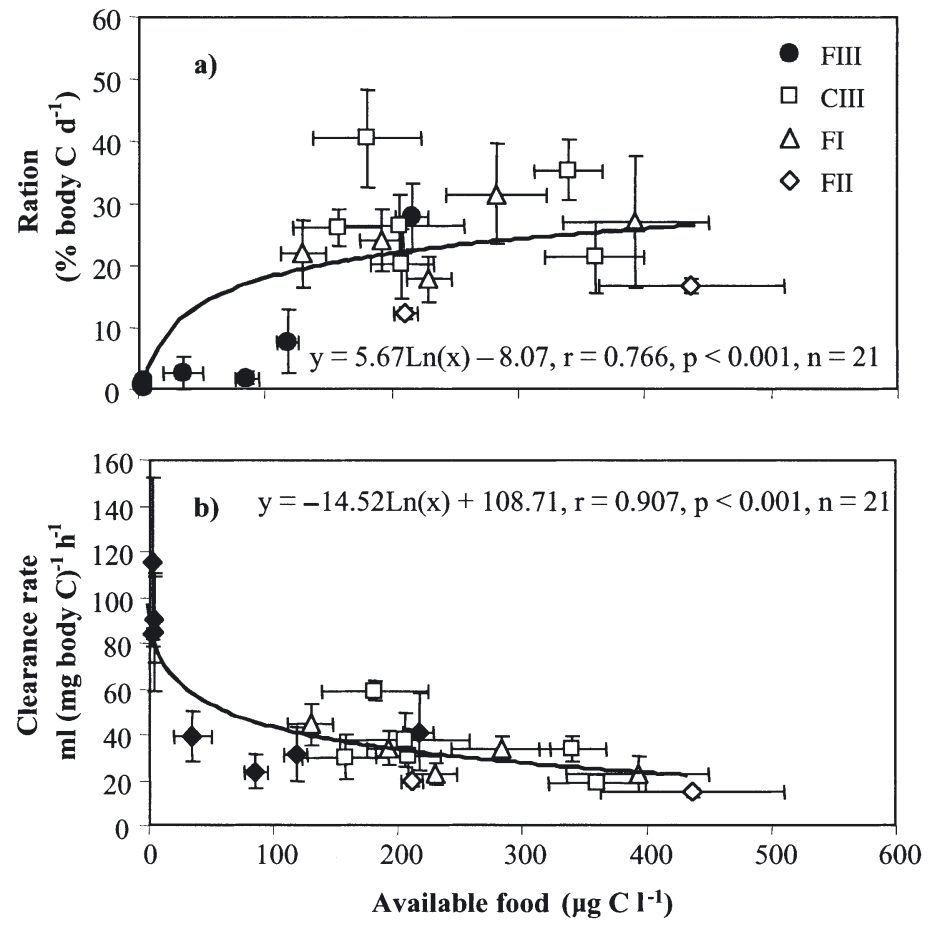

Fig. 7. Euphausia superba. Calyptopis III (CIII), furcilia I, II and III (FI, FII, FIII). Summary of data on daily carbon (C) ration (a) and clearance rate (b) from FIII larvae (Meyer et al. 2002) and the larval stages used in this study. Bars indicate \pm SD of the mean. Regressions were calculated with mean values, $\mathrm{n}=21$

\section{Energy budgets}

Larval growth and development are known to correlate with food quantity and/or nutritional quality (Ikeda \& Dixon 1982, Brinton \& Townsend 1984, Huntley \& Brinton 1991, Ross et al. 2000). Studies on adult krill by Clarke et al. (1988) and Pond et al. (1995) indicate that food quality has an important effect on digestion rate and hence assimilation efficiency. A high assimilation efficiency indicates good nutritional value of the available food. Diatoms are a valuable food for krill (Habermann 1998) and dominated the phytoplankton composition during our study period. These were accompanied by a rich and varied microheterothroph assemblage (Table 3). The larvae off Rothera showed high assimilation efficiencies (AEs) ranging between 70 and $92 \%$. Similar values for adult krill were estimated by Kato et al. (1982; AE: 72 to $94 \%$ ) and Haberman (1998; AE: 65 to $97 \%$ ). Given the high DR (Table 4), respiratory C losses (RLs), especially in CIII and FI, seem to be low but in a comparable range to values from other studies. Ikeda (1984) reported a daily RL of $1.8 \%$ in FI to FIII during summer, Meyer et al. (2002) recorded values of 2.3 to $3.9 \%$ for well-fed FIII in autumn, and Frazer et al. (2002) found losses of $1.3 \%$ in laboratory-fed larval krill at winter temperature. However, the given RLs combined with high AEs certainly gives the larvae off Rothera plenty of scope, either to increase lipid reserves or to grow.

The mean gross growth efficiency (GGE) of CIII to FII calculated in our study (Table 4) was 1.7 times more than that of Ikeda (1984) for CI through to FVI in laboratory experiments. Given the extremely high food concentrations Ikeda used (1370 to $5480 \mu \mathrm{g} \mathrm{C}^{-1}$ ), krill larvae in the wild may achieve higher GGEs, because lower food concentration and/or a high quality of food have been shown to result in a higher GGE (Ikeda 1984).

Clearly in any determination of a zooplankter's energy budget, there is scope for error in all of the component measurements. Metabolic rates of krill that are not feeding (e.g. in respirometers) are lower than those of krill that are feeding (Ikeda \& Dixon 1984, Atkinson \& Whitehouse 2000). Our method of estimating assimilation rate also needs intercomparison with more traditional methods. Notwithstanding uncertainties such as these, it is clear from the condition of the larvae and the large surplus of $\mathrm{C}$ available for growth that food quality and quantity were optimal at Rothera.

Recent studies on krill larvae, including the SOGLOBEC initiative, have highlighted the importance of the seasons of sea-ice in larval survival and krill

Table 4. Euphausia superba larvae. Energy budget, in terms of body carbon, of different larvae from off Rothera (Marguerite Bay), calyptopis (CIII), furcilia I and II (FI, FII). Body carbon (BC), daily ration (DR), ingestion rate (IR) and assimilation rate (AR), and respiratory carbon loss (RL) are mean values of all measurements of each larval stage during the study period. Egestion (E), total growth $(G)$ and gross growth efficiency (GGE) are calculated from our measured values

\begin{tabular}{|c|c|c|c|c|c|c|c|c|c|c|}
\hline \multirow{2}{*}{$\begin{array}{l}\text { Larval } \\
\text { stages }\end{array}$} & \multirow[b]{2}{*}{$\begin{array}{c}\text { BC } \\
(\mu g)\end{array}$} & \multicolumn{6}{|c|}{ Measured } & \multirow[b]{2}{*}{$\begin{array}{c}E \\
(E=I-A) \\
\left(\mu g \mathrm{Cd}^{-1}\right)\end{array}$} & \multirow{2}{*}{ 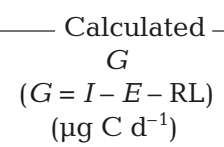 } & \multirow[b]{2}{*}{$\begin{array}{c}\text { GGE } \\
(\mathrm{GGE}=\mathrm{G} / I) \\
(\%)\end{array}$} \\
\hline & & $\begin{array}{c}\mathrm{DR} \\
\left(\% \mathrm{~d}^{-1}\right)\end{array}$ & $\begin{array}{c}\mathrm{IR} \\
\left(\mu \mathrm{C} \mathrm{d}^{-1}\right)\end{array}$ & $\left(\% \mathrm{~d}^{-1}\right)$ & $\begin{array}{l}\mathrm{R} \\
\mu \mathrm{g}\left(\mathrm{Cd}^{-1}\right)\end{array}$ & $\left(\% d^{-1}\right.$ & $g\left(\mathrm{~d}^{-1}\right)$ & & & \\
\hline CIII & 78.1 & 25.9 & 20.2 & 86.2 & 17.4 & 1.6 & 1.2 & 2.8 & 16.2 & 79.9 \\
\hline FI & 127.4 & 26.2 & 33.4 & 87.5 & 29.1 & 1.4 & 1.7 & 4.2 & 27.4 & 82.3 \\
\hline FII & 196.4 & 14.6 & 28.7 & 86.8 & 25.1 & 2.0 & 3.8 & 3.7 & 21.2 & 73.4 \\
\hline
\end{tabular}


recruitment (e.g. Daly 1990, Frazer et al. 2002, Meyer et al. 2002). However, understanding functional relationships between growth and food is important at all times of year for a better understanding of how krill recruitment is controlled. Whether food is pelagic or derived from the ice, we need basic information on energy budgets and functional responses for krill in the critical first year of their life.

Until the last few years, the Marguerite Bay area was almost unknown as a krill habitat, with most work occurring further north along the Antarctic Peninsula. Recent findings of high abundances of krill larvae close inshore at Rothera (this study), as well as abundances up to 100 ind. $\mathrm{m}^{-3}$ offshore (Atkinson et al. 2002a), raise the question over the role of such southward habitats as population nuclei. This study, plus the limited starvation tolerance of larvae (Quetin \& Ross 1989), suggests that krill larvae would not grow well in the $<1 \mathrm{mg} \mathrm{m}^{-3} \mathrm{chl}$ a concentrations which typify large areas of the Southern Ocean. A dependence of high phytoplankton concentrations for a large part of the season, whether in ice or in open water, may be prerequisites for successful recruitment. The notion that such productive shelf regions operate as summer 'nurseries' for larvae, maintaining high populations in the SW Atlantic, needs to be explored.

Acknowledgements. First, we would like to thank the Base Commander P. Rose and his staff at the British Antarctic Station Rothera, for their hospitality during our visit there. We are particularly indebted to J. Beaumont for helping us organise the lab work and collecting the environmental information, I. MacDonald for providing a boating service and Dr. L. Peck for allowing us to use his couloximeter. Unpublished data from the Rothera Time Series (RATS) monitoring station were collected by J. Beaumont and were kindly made available by Prof. A. Clarke. The manuscript was improved substantially by the comments of 3 anonymous reviewers. This work was supported by funding from the German Federal Ministry of Education and Science (BMBF), through the project 'Seasonal nutrition strategy of Antarctic krill (Euphausia superba)', project number 03PL025A. This is Publication awi-n 11060 of the Alfred Wegener Institute.

\section{LITERATURE CITED}

Atkinson A (1995) Omnivory and feeding selectivity in five copepod species during spring in the Bellingshausen Sea, Antarctica. ICES J Mar Sci 52:385-396

Atkinson A, Snÿder R (1997) Krill-copepod interactions at South Georgia, Antarctica, I. Omnivory by Euphausia superba. Mar Ecol Prog Ser 160:63-76

Atkinson A, Whitehouse MJ (2000) Ammonium excretion by Antarctic krill Euphausia superba at South Georgia. Limnol Oceanogr 45:55-63

Atkinson A, Bathmann UV, Blume B, Oettl B, Meyer B (2002a) Overall abundance and age composition of krill. In: Bathmann UV (ed) Rep Polar Res 407. Alfred Wegener Institute, Bremerhaven, p 26-27
Atkinson A, Meyer B, Stübing D, Hagen W, Schmidt K, Bathmann UV (2002b) Feeding and energy budgets of Antarctic krill Euphausia superba at the onset of winter. II. Juveniles and adults. Limnol Oceanogr 47:953-966

Båmstedt U, Gifford DJ, Irigoien X, Atkinson A, Roman M (2000) Feeding. In: Harris RP, Wiebe PH, Lenz J, Skjoldal HR, Huntley M (eds) ICES zooplankton methodology manual. Academic Press, London, p 297-399

Brinton E, Townsend AW (1984) Regional relationships between development and growth in larvae of Antarctic krill, Euphausia superba, from field samples. J Crustac Biol 4(spec no 1):224-246

Clarke A, Quetin LB, Ross RM (1988) Laboratory and field estimates of the rate of faecal pellet production by Antarctic krill, Euphausia superba. Mar Biol 98:557-563

Daly KL (1990) Overwintering development, growth and feeding of larval Euphausia superba in the Antarctic marginal ice zone. Limnol Oceanogr 35:1564-1576

Donnelly J, Torres JJ, Hopkins TL, Lancraft TM (1990) Proximate composition of Antarctic mesopelagic fishes. Mar Biol 106:13-23

Fraser FC (1936) On the development and distribution of the young stages of krill (Euphausia superba). Disc Rep 14: 1-192

Frazer TK, Quetin LB, Ross RM (1997) Abundance and distribution of larval krill, Euphausia superba, associated with annual sea ice in winter. In: Battaglia B, Valencia J, Walton DWH (eds) Antarctic communities: species, structure and survival. Cambridge University Press, Cambridge, p 107-111

Frazer TK, Quetin LB, Ross RM (2002) Energetic demands of larval krill, Euphausia superba, in winter. J Exp Mar Biol Ecol 277:157-171

Frost BW (1972) Effects of size and concentration of food particles on the feeding behavior of the marine planktonic copepod Calanus pacificus. Limnol Oceanogr 17:805-815

Habermann KL (1998) Feeding ecology of the Antarctic krill, Euphausia superba: the role of phytoplankton community composition in the krill's diet. PhD thesis, University of California, Santa Barbara

Hagen W (1988) On the significance of lipids in the Antarctic zooplankton. Rep Polar Res 49:1-129

Hempel I (1985) Variation in geographical distribution and abundance of larvae of Antarctic Krill, Euphausia superba, in the Southern Atlantic Ocean. In: Siegfried WR, Condy PR, Laws RM (eds) Antarctic nutrient cycles and food webs. Springer-Verlag Berlin, p 305-307

Holland DL, Gabbott PA (1971) A micro-analytical scheme for the determination of protein, carbohydrate, lipid and RNA levels in marine invertebrate larvae. J Mar Biol Assoc UK 51:659-668

Huntley M (1981) Nonselective, nonsaturated feeding by three calanoid copepod species in the Labrador Sea. Limnol Oceanogr 26:831-842

Huntley M, Brinton E (1991) Mesoscale variation in growth and early development of Euphausia superba Dana in the western Bransfield Strait region. Deep-Sea Res 38: 1213-1240

Ikeda T (1981) Metabolic activity of larval stages of Antarctic krill. Antarct J US 16:161-162

Ikeda T (1984) Development of the larvae of the Antarctic krill (Euphausia superba Dana) observed in the laboratory. J Exp Mar Biol Ecol 75:107-117

Ikeda T, Dixon P (1982) Body shrinkage as a possible overwintering mechanism of the Antarctic krill, Euphausia superba Dana. J Exp Mar Biol Ecol 62:143-151

Ikeda T, Dixon P (1984) The influence of feeding on the meta- 
bolic activity of Antarctic krill (Euphausia superba Dana). Polar Biol 3:1-9

Ikeda T, Torres JJ, Hernández-León S, Geiger SP (2000) Metabolism. In: Harris RP, Wiebe PH, Lenz J, Skjodal HR, Huntley M (eds) ICES zooplankton methodology manual. Academic Press, London, p 455-520

Johnson MA, Macaulay MC, Biggs DC (1984) Respiration and excretion within a mass aggregation of Euphausia superba: implications for krill distribution. J Crustac Biol 4:174-184

Kato M, Segawa S, Tanoue E, Murano M (1982) Filtering and ingestion rates of the Antarctic krill, Euphausia superba Dana. Trans Tokyo Univ Fish 5:167-175

Lowry OH, Rosebrough NJ, Farr AL, Randall RJ (1951) Protein measurement with the Folin Phenol reagent. J Biol Chem 193:265-275

Marschall HP (1985) Structural and functional analyses of the feeding appendages of Krill larvae. In: Siegfried WR, Condy PR, Laws RM (eds) Antarctic nutrient cycles and food webs. Springer-Verlag Berlin, p 346-354

Mauchline JJ, Blaxter HS, Southward AJ, Tyler PA (1998) Advances in marine biology: the biology of calanoid copepods. Academic Press, San Diego

Medlin L, Priddle J (1990) Polar marine diatoms. British Antarctic Survey, Cambridge

Menden-Deuer S, Lessard EJ (2000) Carbon to volume relationships for dinoflagellates, diatoms and other protist plankton. Limnol Oceanogr 45:569-579

Meyer B, Atkinson A, Stübing D, Oettl B, Hagen W, Bathmann UV (2002) Feeding and energy budgets of Antarctic krill Euphausia superba at the onset of winter-I. Furcilia III larvae. Limnol Oceanogr 47:943-952

Paulus H (1996) Arthropoda, Gliederfüßer. In: Westheide W, Rieger R (eds) Spezielle Zoologie. Gustav Fischer Verlag, Stuttgart, p 411-419

Peck LS, Whitehouse MJ (1992) An improved desorber design for use in couloximetry. J Exp Mar Biol Ecol 163:163-167

Pond DW, Priddle J, Sargent JR, Watkins JL (1995) Laboratory studies of assimilation and egestion of algal lipid by Antarctic krill-methods and initial results. J Exp Mar Biol Ecol 187:253-268

Priddle J, Fryxell G (1985) Handbook of the common plank-

Editorial responsibility: Otto Kinne (Editor),

Oldendorf/Luhe, Germany ton diatoms of the Southern Ocean, Centrales except the genus Thalassiosira. British Antarctic Survey, Cambridge

Quetin LB, Ross RM (1989) Effects of oxygen, temperature and age on the metabolic rate of the embryos and early larval stages of the Antarctic krill Euphausia superba Dana. J Exp Mar Biol Ecol 125:43-62

Ross RM, Baker S (1999) Palmer LTER: annual January cruise for 1997 (PD97-1). Antarct J US 32:13-14

Ross RM, Quetin LB (1991) Ecological physiology of larval Euphausiids, Euphausia superba (Euphausiaceae). Mem Qld Mus 31:321-333

Ross RM, Quetin LB, Baker KS, Vernet M, Smith RS (2000) Growth limitation in young Euphausia superba under field conditions. Limnol Oceanogr 45:31-43

Schmidt K, Atkinson A, Stübing D, McClelland JW, Montoya JP, Voss M (2003) Trophic relationships among Southern Ocean copepods and krill: some uses and limitations of the stable isotope approach. Limnol Oceanogr 48: $277-289$

Siegel V (2000a) Krill (Euphausiacea) demography and variability in abundance and distribution. Can J Fish Aquat Sci 57:151-167

Siegel V (2000b) Krill (Euphausiacea) life history and aspects of population dynamics. Can J Fish Aquat Sci 57:130-150

Thomas CR, Hasle GR, Steidinger KA, Syvertsen EE, Tangen K (1996) Identifying marine diatoms and dinoflagellates. Academic Press, San Diego

Ward P, Grant S, Brandon M, Siegel V, Sushin V, Loeb V (in press) Mesozooplankton community structure in the Scotia Sea during the CCAMLR Survey: January, February 2000. Deep Sea Res II

Wright SW, Jeffrey SW, Mantoura RFC (1997) Evaluation of methods and solvents for pigments extraction. In: Jeffrey SW, Mantoura RFC, Wright SW (eds) Phytoplankton pigments in oceanography. UNESCO Publishing, Paris, p 261-282

Zöllner N, Kirsch K (1962) Über die quantitative Bestimmung von Lipoiden (Mikromethode) mittels der vielen natürlichen Lipoiden (allen bekannten Plasmalipoiden) gemeinsamen Sulfophosphovanillin-Reaktion. Z Ges Exp Med 135:545-561

Submitted: November 14, 2002; Accepted: May 5, 2003 Proofs received from author(s): July 17, 2003 